\title{
THE MYTH OF NASSER'S ARABISM. CAIRO (1956-1970), A POLITICAL-URBAN PARADOX
}

\author{
Sadek Saad \\ Department of Architectural Engineering \\ Shobra College of Engineering, Benha University, Cairo, Egypt
}

\begin{abstract}
Nasser (1956-1970) was known for his devotion to Arabism. Meanwhile, the place should reveal political, cultural, social, and economic parameters for everyday life.

This study aims at tracing the consistency between Nasser's slogan of Arabism and his authoritarian urban and architectural products. Descriptive and analytical research methods are implemented.

The society could be studied through the building of the city. Instead of stressing on Arabism as an urban and architectural identity, Nasser's authorities promoted westernization and disconnection with local Arabic history. Nasser fell into the colonial trap by promoting the European city model for local urbanization.
\end{abstract}

Keywords - Planning History; Urban History; Cairo; The Power Theory; The Sociocultural Aspects; Nasser; Urban Studies; Egyptian Urbanization

\section{INTRODUCTION}

In July 1952, a group of young army officers known as the 'Free Officers' led a military movement that resulted in the banishment of King Farouk and established the Republic of Egypt. The mere king's banishment was perceived as the end of the 'fogy' system and the beginning of a new 'progressive' one. Detaching 'now' from 'then' -or the progressive Republic from the retrospective monarchy- was a clear ground for destructing 'the old system rather than the construction of the fresh one (Sabaseviciute 2011, 1, 9).

Presenting themselves as political successors of Urabi's revolt (1881), the Free Officers showed a revolutionary image. They were creating a historical continuity in the liberation movement of anti-colonialism, "which was repeatedly repressed by enemy forces in the past (Sabaseviciute 2011, 9). Clamming Urabi's political legacy aimed at establishing legitimacy for their movement since Urabi was also an officer and the public held him as a national hero. Furthermore, rapid urban development ought to strengthen their legitimacy because urban projects provide means of distributing patronage (Moor 1994)

The city is a necessary point of passage in the exploration of the socio-spatial dynamics of the state. The city should be seen as space where demands are made, and the local actors are performing specific functions within global circuits of contention (Allen 2010). Since cities can become the focus of mobilizing local identities (Bernardo and Palma-Oliveira 2012), Nasser paid much attention to urban development to exercise his political power. Later, Nasser found difficulties in funding his urban ambitions with the economic crisis of 1965 (Sims 2012).

Nasser did not invent Arabism; he seized the idea to promote his politics in the Arab world via cultural slogan (Sadek 2006, 158). In 1958, Nasser's efforts to create Arab unity established the United Arab Republic (UAR) with Syria. Dunn sees his Arab unity's promotion and cultural protecting as evidence for structuring the Arabic nationality (Dunn n.d.). Throughout his speeches and writings, Nasser declared such an attitude (Nasser n.d.). He said: 'Imperialists were not happy with dominating the Arab peoples materially, but extended their domination to intellectual factors as well, seeking to rob them of their Arabic language, the depository of their national intellect and tradition.' (Nasser 1962) This statement proves that Nasser was very aware of the self-identification of local cultural necessity and the need to rebuild a new sociocultural and political Arabic mechanism.

Nasser proved his awareness of colonialism's impact on local Arab culture; Arabism was his political response against such an impact. Nasser stressed on implementing the Arabic language in education, media, cultural activities, and civic life. Cairo's centrality in the social, cultural, and political networks of the Arab world strengthened Nasser's political power and ideology of Arabism (Hanssen 2020), but was his authoritarian urban and architectural products consistent with his political slogan?

In 1961, Nasser and several Third World leaders met for the first Summit of the Non-Aligned Movement (NAM) in Belgrade -a Soviet alley. After that Summit, a definite shift in Nasser's political agenda took place. Egypt, which ended up somewhat aligned to the Soviet Union out of the need for resources and military support in a bilateral world, was not neutral. However, Nasser continued promoting the ideology of Arabism and neutralism. In this sense, his political agenda was inconsistent.

\section{STUdy AIM AND METHODS}

Since the urban space is a place of collective consciousness' production (Kavoura n.d.), this study aims at 


\section{International Journal of Engineering Applied Sciences and Technology, 2020 \\ Vol. 5, Issue 5, ISSN No. 2455-2143, Pages 37-45 \\ Published Online September 2020 in IJEAST (http://www.ijeast.com)}

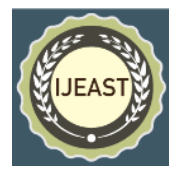

tracing the impact of Nasser's Arabism on the Cairo authoritarian built environment and find consistency between the slogan of Arabism in theory and implementation. Dunn argued that 'Nasser was best known for his [...] dedication to Arab unity' (Dunn n.d.). However, did he face the dilemma between inherited Egyptian sociocultural forces, Arabism, and 'modernization' in practice?

An essential point in the relationship's exploration between politics and urbanism is tracing and comparing what was built during a specific period to match its slogans with actions since authoritarian urbanism demonstrates the actual political action. Cairene authoritarian architecture and urban development during Nasser's era will be described and compared to Nasserist literature, news articles, and design criteria. Interpretation of architectural and urban styles during Nasser's era would help find their relationship with Nasser's political agenda. It should help in answering the study question: was Nasser's urban and architectural development consistent with his Arabism slogan?

\section{AUTHORITERIAN ARCHITECTURE AND URBANIZATION IN CAIRO (1956-1970)}

Place identities are considered 'place frames for collective action: selective but shared experiences' (Uitermark, Nicholls, and Loopmans 2012). Space has significance for everyday life, 'society could be studied spatially through the buildings of the city' (Kumar 2017, 1032).

During the Nasser era (1956-1970), several urban, rural, and architectural projects were created. The Cairo Tower, the Arab League Headquarters, the Arab Radio, and Television central building, the Nile Hilton Hotel, and the Socialist Union Headquarters are Nasser's achievements' architectural landmarks. Several urban projects were also constructed, such as Medinet el-Sahafeyyen (the journalists' city), Medinet elMohandseen (the engineers' city), and his urban crown achievement: Medinet Nasr (the city of victory). Although they were more like quarters than towns, they were labelled: cities. Several industrial areas in the north and south of Cairo and several low-income housing areas were created. Gehan Selim considered those projects as attempts for 'imposing imaginary superficial modernity' (Selim 2016, 182); however, some of them revealed Nasser's socialist ideology.

'Midan el-Isamiliyya,' renamed after July 1952 'Midan elTahrir,' is a place associated with decolonization memories since the place witnesses the British troops' evacuation which occupied Egypt and settled in the Qasr al-Nil barrack in Midan el-Tahrir in 1882. The landscape of Midan el-Tahrir and its architectural context can be seen as a summation of the $19^{\text {th }}$ and the $20^{\text {th }}$ centuries' authoritarian modernism and political shifts. Buildings such as the Museum of the Egyptian Antiquities, the Mogamma, the Socialist Union headquarters, the Nile Hilton hotel, a bus terminal and the American University in Cairo, present different cultural and political meanings. Midan el-Tahrir creates a relationship with the Soviet-Stalinist style in Public Square design (Föllmer 2018).
At the Midan centre, a traffic roundabout with a statue granite base was constructed in the 1870 s but remained empty until it was demolished in 2020. The Museum of Egyptian Antiquities was constructed in the early $19^{\text {th }}$ century, adopting a colonial style. A royal palace was reused as the Ministry of Forging Affair's headquarters by the beginning of the $20^{\text {th }}$ century. The old campus of the American University in Cairo occupied another royal palace from the late $19^{\text {th }}$ century. The Nile Hilton hotel, designed by an American architect to represent the USA's efficiency and luxury. A bus terminal was designed for presenting Egypt modernity and political centrality.

Medinet Nasr was a megaproject, it was planned to hostess the Egyptian Olympic Village, the new campus of el-Azhar University with its 'modern' colleges for applied science, ministries' headquarters and ten residential districts. It was constructed on a military-owned vast desert area in the eastern suburbs of Cairo (Medinet Nasr Company (Ed.) 2019). It promoted modern British rules (Dorman 2013) and zoning in urban planning because zoning controls allowable uses and buildings form (Talen 2012, 331). The Egyptian planner of Medinet Nasser presented "The socialist Villa," claiming that such a residential type is suitable for Egyptians' middleincome and intellectual classes in the 1960s (Karim, n.d.). He claimed that the socialist villa was promoting Nasser's sociopolitical progressive vision. Nevertheless, 'urban form is just an insert receptor of eternally imposed order' (Norberg-Schulz 1991, 166), and such imposed order could change its outcome. Medinet Nasr that aimed at drawing the middle and working classes away from Cairo ended up being so expensive to live in that 'the wealthy moved in instead' (Bale and Blake 2017), and its urban form changed.

Fig. 1. Medinet Naser Street Pattern, with courtesy of Medinet Naser Company for Residential and Urban Development

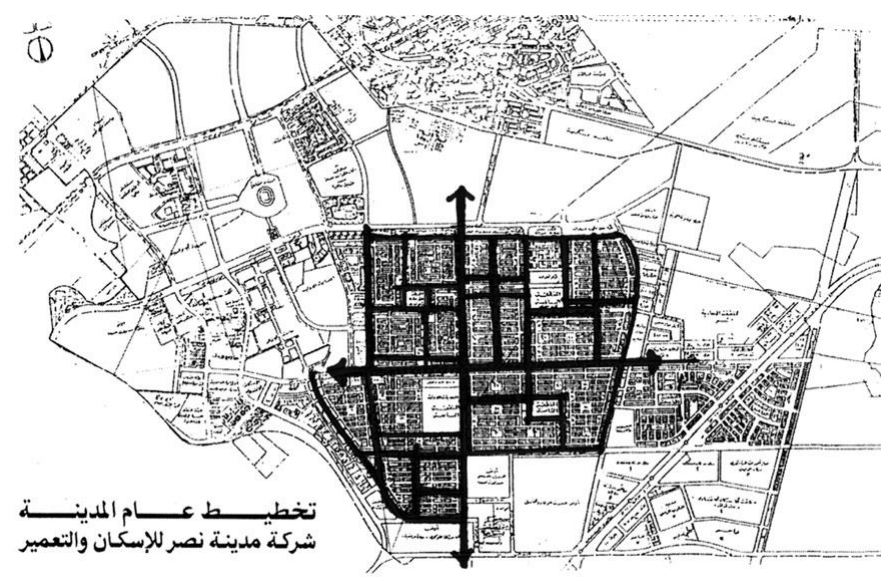

The original master plan of Medinet Nasr shows an understanding of the importance of Public Squares (Figure 1). Its implementation created vacant lands, central open areas, and road patterns instead. Medinet Nasr revealed a definite shortage in public places, since 'in a city where ownership of 


\section{International Journal of Engineering Applied Sciences and Technology, 2020 \\ Vol. 5, Issue 5, ISSN No. 2455-2143, Pages 37-45 \\ Published Online September 2020 in IJEAST (http://www.ijeast.com)}

public space is centralized, good urban design is undersupplied' (Webster 2007, 98). It revealed the centrality and authoritarian power of the Nasser regime in implementation. Although the city's various autonomous systems, 'each with its logic, mean that nobody could coordinate everything' (Sudradjat 2012, 33), and despite Nasser's socialist slogan, he thought differently. He thought urban development could be created without state-society negotiation (Dorman 2013), in order to be consistent with his 'authoritarian high modernism' (Scott 1998).

Among all structures built in Cairo Down Town's western area, the Arab League headquarters is the only building showing few Arabic decorations (Figures 2 and 3). Its decorations look very superficial to be considered as part of the building architectural design, especially if the building is compared to other buildings in Cairo Down Town from the era called the 'belle époque.' Following the 1952 movement, many buildings from the old era were converted to state-owned facilities, and significant palaces of the old regime were confiscated by the state and were reused as schools, governmental offices, or military headquarters.

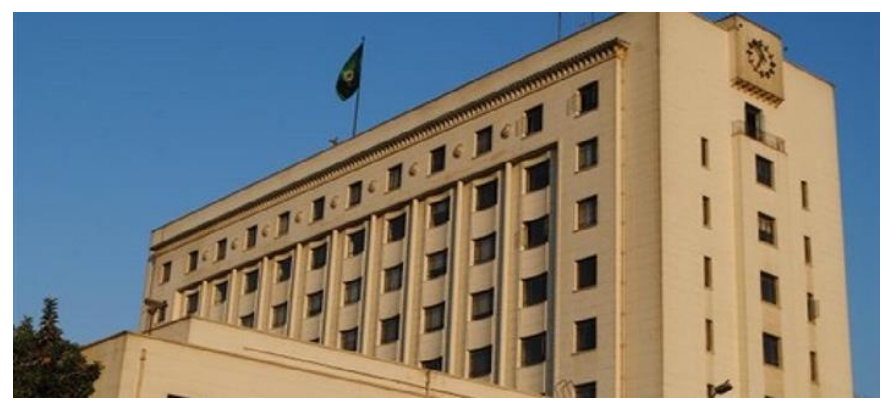

Fig. 2. The Arab League Headqueters, the author

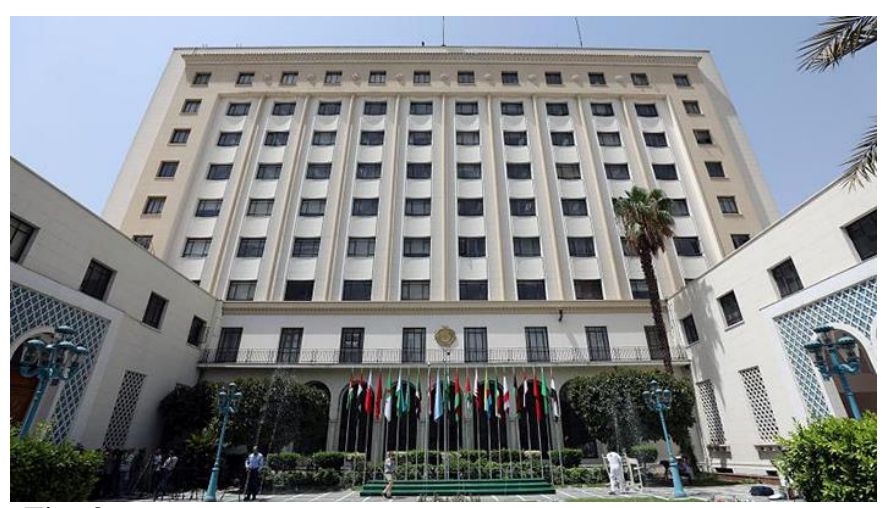

Fig. 3. The Arab League Headquarters' main entrance, the author

The City Centre and the historic Cairo were considered antiquities from a decaying past, thus were treated as touristic site seeing. Since Cairo Down Town was seen as a colonial symbol, it was neglected by the Nasser regime. Few urban interventions took place during the Nasser era, but some old regime's projects were completed. One of Nasser's urban interventions was dividing the Azbakeya garden into two smaller ones with a major road as a percée: the $26^{\text {th }}$ of July Street. Azbakeya garden was constructed as a royal garden during Ismail Pasha's reign (1862-1879) and as a vista for several streets. The garden was considered a symbol of sociocultural discrimination by Nasser's regime. Public theatres were built inside the garden and periphery to promote the new cultural progressive age, undermine the place's historical symbolic meaning, and attract intellectuals from attending the Royal Opera house nearby. Old streets were renamed after the new political and military prominent and revolutionary events to cleanse all relationship with the past.

The Socialist Union headquarters was constructed in 1958, located northern of Midan el-Tahrir, and overlooking the Nile (Figure 4). It was built over the demolished British Barak and a palace from the Egyptian monarchy to represent the new socialist state's modernity. The emphasis on building's grandeur was intentional because the building represented the socialist state's authoritarian power. Its location overlooking the vast area of Tahrir, the Nile, and the Museum for Egyptian Antiquities increased its visual impact (S. Saad 2018).

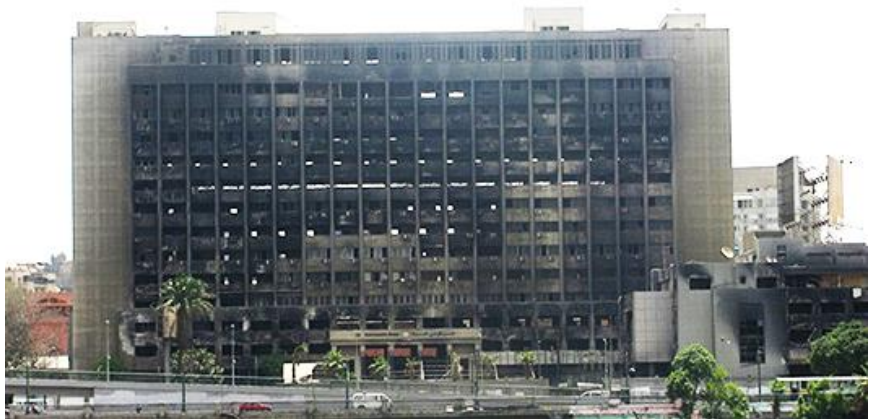

Fig. 4. The Socialist Union after the $25^{\text {th }}$ of January revolution, the author

The Mogamma was gifted by the Soviet Union before 1952 but constructed in 1953 (Figure 5). After establishing the Republic, it stood for the global presence of the central social ideology. The Mogamma represented simplicity, centrality, monumentality, and efficiency of the Egyptian socialist government. Thanks to the typical Soviet Socialist Stalinist style, its grandeur and position stood for the state administrative power. The Mogamma became a 'polluted symbol' (Rabbat 2011) for Egyptian bureaucracy after the fall of socialism in Egypt (following Nasser's death in 1970). The Arabic Radio and Television central building was designed by a French architect and constructed in 1965 at the river Nile's front northern Midan el-Tahrir. Its iconic structure and grandeur stood for the state's media and cultural powers. 


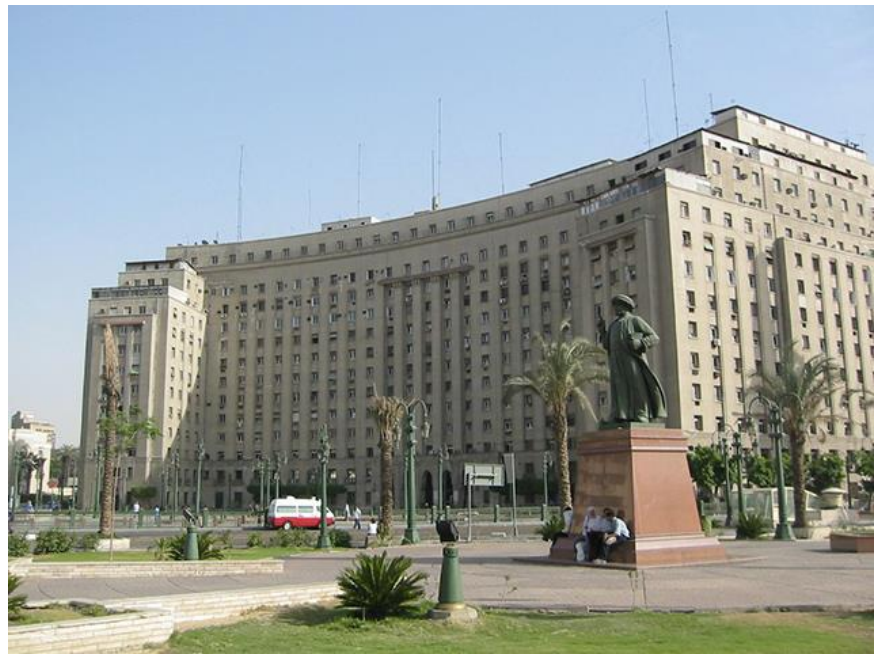

Fig. 5. The Mogamma, the author

Perhaps the genuine triumph of colonialism was not achieved in battles but the fields of culture and education. Culture and education created new embedded historical roots in the way of thinking of both the Egyptians intellectuals and the ordinary Egyptians (S. Saad 2019). During the $19^{\text {th }}$ and $20^{\text {th }}$ centuries, European powers were not only invading the east, 'but "European buildings" styles were cropping up in its cities and shaping their appearance' (Rabbat 2010).

Colonization raised preconceived ideas that military force could maintain the new socialist state's order of things. The question that dominated anti-colonial forces ever since was: what kind of resistance can 'bring about a future unbeholden to Western forms of economic and cultural imperialism' (Hanssen 2020).

\section{SOCIOCULTURAL LEGACY OF EGYPTIAN URBANISM}

During the end of the $19^{\text {th }}$ century and the first half of the $20^{\text {th }}$ century, a national debate among Egyptian intellectuals about Egypt's identity took place to answer a vital question: is Egypt an Arab or an ancient Egyptian country? Egyptian architects were not isolated from such a debate. They showed different attempts to implement either an Arabic architectural character or an Ancient Egyptian one (S. Saad 2020). At the heart of the debate was the relationship between culture, nationality, sovereignty, and Egypt's position within the Arab world, the Islamic world was excluded (Sabaseviciute 2011).

Neither Ismail Pasha (1863-1879) nor his successors claimed to promote Arabism, but architecture during their eras presented a real debate between Arabic and Ancient Egyptian styles. Even if they were considered superficial, such debate produced richness in the Egyptian architecture and produced the neo-Mamluk style. 'The neo-Mamluk style owed its creation to the confluence of various intellectual, architectural and political currents which developed over the $19^{\text {th }}$ century'(Rabbat 2010).
Parallel to the intellectual debate about the Egyptian identity, Heliopolis designed and planned in 1910. It was the achievement of a Belgium urban development company owned by the Baron 'Edward Empain'. Its architecture adopted a style that might be considered similar to the 'neo-Mamluk' but in a different visual mixture. Heliopolis's architecture presented a mixture of motives and elements from distinct parts of the Muslim World, from Andalusia to India (Figure 6).

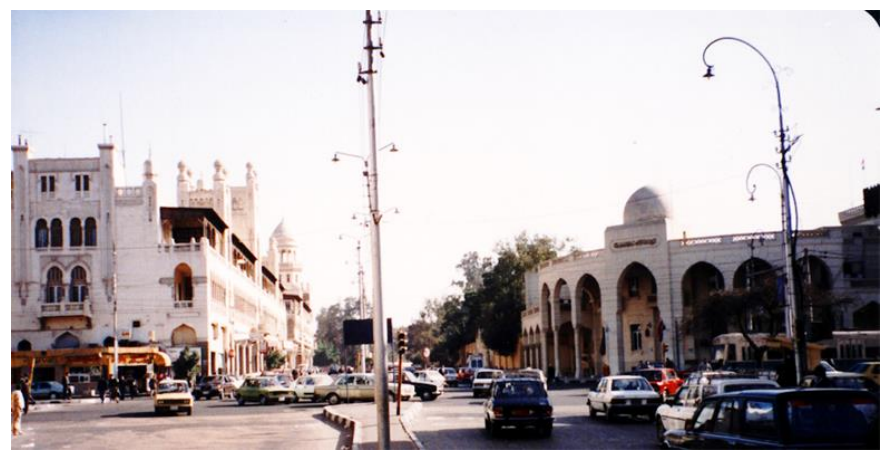

Fig. 6. Heliopolis, the author

The view of Arab history as part of the European history creates a cultural 'connecting link' between both cultures but ignored their diversity. Arabic literature was 'organized and studied in the same roles as a European 'historical development' (Mitchell 1991, 169-70).

Al-Azhar University, the literature of Taha Hussien, the international film festival, or the timeless songs of UmKulthum, are components used in strengthening Egyptian cultural relationships within the Arab world, but architecture and urbanization were not. Whether the cultural debate between intellectuals did not create the required urban effect or westernization had a dominant cultural impact, Nasser did not invest Egypt's influential urbanization position in promoting his slogan. By adapting the western modernism, Nasser generated the impression that Arabism is not related to local modernism.

Westernization became indisputable within the Arab and Egyptian intellectuals. Klufis Maksoud, Hassanien Haykal, and others wrote about the crisis of intellectuals. Maksoud (1960) wrote: 'Crisis of the Arab Left,' and a year later, Haykal (1961) wrote: 'The Crisis of the Intellectuals.' They both criticize the Intellectuals' cultural public role, but they offered no solution. While Maksoud's (Maksoud 1960) analysis 'remained locked in leftist battles for position' (Hanssen 2020), Haykal's (Haykal 1961) point of view did not exceed the colonialism cultural background. Ironically, Maksoud and Haykal both studied in the American University in Beirut and Cairo, respectively. Standing from the superiority of the colonial culture, they both applied western cultural criteria in evaluating on the Arab World culture.

Maybe the conceptual approach of designing public spaces during Nasser's era was motivated by the socio-political 


\section{International Journal of Engineering Applied Sciences and Technology, 2020 \\ Vol. 5, Issue 5, ISSN No. 2455-2143, Pages 37-45 \\ Published Online September 2020 in IJEAST (http://www.ijeast.com)}

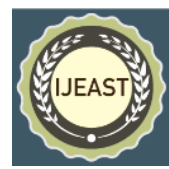

system pattern, but Midan el-Tahrir and several significant boulevards adopted the Soviet-Stalinist styles. Midan elTahrir was designed through a political process of placemaking, presenting the key to understanding how Socialist dictators conceptualize and impose their urban products on 'the socio-spatial re-ordering of the urban environment' (Pierce, Martin, and Murphy 2010, 55). The vast area of Midan el-Tahrir impressed its visitors with its visual dominancy, representing the centrality of new authorities. The development of Midan el-Tahrir aimed at stressing on different political and cultural aspects, but none of them presented Nasser's Arabism. It was designed to be a traffic and transportation central node and not a public urban space for collective socio-political gathering.

Social space is the realm in which society's cultural life is enacted to receive whatever is poured into it, 'if it is produced by the pattern of social interaction' (Kumar 2017, 1032). However, public spaces during the Nasser era were not produced by any socio-political negotiation. The political and administrative centrality of his regime monopolized the production of public spaces. Like other cities, Cairo is an incubator of broader struggles to account for how 'the local state affects the socio-spatial development of social movements' (Uitermark, Nicholls, and Loopmans 2012). No public debate -to define modernism- and no public engagements in Cairo urbanization took place, despite the regime's political stands for local socio-culture aspects. During the Nasser era, Egyptian urbanization's symbolic meanings were related to the military elites' sociocultural backgrounds and their intellectuals, which saw westernization as a synonym for modernism and control as a vital method of preventing counter-revolution.

\section{NASSER's ARCHITECTURAL AND URBAN PARADOX}

Urbanism is the product of a governing network of forces or players (Pflieger and Rozenblat 2010). It should show different identities according to different types of urban forces (Hiller and Iida 2005). No matter what is claimed by a player, the built environment's identity will show characters, symbols, and signs of the governing network (S. Saad 2019). Proving Egypt was moving away from its past, Cairo's new visual appearance became characterized by notions of international styles of architecture and planning (Selim 2016, 196). Nasser's political agenda was clear in defeating the 'old retroactive' political system but not consistent with creating a new Arabic one. Down Town or 'Ismailiah' became an urban symbol 'of colonial culture' (Abaza 2011, 1080). Thus, it was neglected, and Nasser urban developments moved to other areas; Shobra at the north, Helwan at the south, and Medinet Naser at the east -near Heliopolis (another symbol of the colonial era). Thus, borrowing 'rationality' and 'modernity' from the West were his tools (Badie 2000). The creation of wide straight celebrative roads, civic institutions, commercial centers, and reinforcing building regulations were modernization and Europeanization statements (Hein 2012, 374).
As liberation called ideas of national identity, planning new districts should present urban identity associated with the regime's representation of its political values. Nasser's political agenda required a break with the old order to proclaim the transformation of all spheres of life, including the public realm, under the rising call for modernization and urban order (Selim 2016, 182). Nevertheless, the colonial rule, and mainly the 'carrot' of independence built into the Mandate system after World War I, put Nasser in a predicament between his political slogan of Arabism and the constructed reality and practice (Hanssen 2020). The colonialism paradigm was the architecture of the colonial city. It was distinguished not just by representation's extent, but also by the very techniques implemented in urban development. However, in the colonial order, the urban effect would always appear as if it was a 'conceptual structure' (Mitchell 1991). Creating a national identity required a revolutionary action against the colonial paradigm. However, Nasser implemented the same methods and techniques of the colonial urbanization for creating a spectacular image of Cairo. Shifting from the $19^{\text {th }}$-century Egyptian urbanization and architecture to the second half of the $20^{\text {th }}$ century was more superficial than it could be considered a revolutionary development.

The reorganization of towns and the laying out of new representative quarters is some pervasive process of 'order'. It can be understood as more than mere improvement or 'reform.' Nasser projects had to be taken as the results of representing a realm of the conceptual, conjuring up for the prior abstractions of progress, reason, law, discipline, colonial authority, and order (Mitchell 1991, 171, 178). Van der Westhusizen and Cloen argued that the colonial towns in South Africa were developed through processes of preconceived design ideas, since, 'the gridiron plan and axial arrangement of streets provided clear legibility' (van der Westhuizen and Cloen 2012, 319) and such preconceived ideas seemed to dominate the Egyptian authoritarian urban memory.

Zad argued that Tehran's architecture during the modernism attempt 'found an eclectic expression to reflect an alternative lifestyle' (Zad 2013, 51, 59). The extroverted style was adapted to reflect cultural symbolism and the power of the new social classes. While westernization was a console and free will of Ismail Pasha (1863-1879), Nasser unconsciously might have implemented it. Ironically, Nasser promoted the same colonial urban components: wide celebrative roads, spectacle streets, monumental buildings with authorities' power representation, and the extroverted concepts in architectural design.

In the search for modernism during the $19^{\text {th }}$ and the first half of the $20^{\text {th }}$ century, local urbanization and architecture lost their local identity. Shifting from the introverted design of the traditional Arabic urbanization and architecture in Cairo (Bianca 2000) to the western extroverted approach, created a superficial appearance of the local character even in 'the neoMamluk style' (Rabbat 2010). The neo-Mamluk and Heliopolis styles gave the Egyptian architecture an external 


\section{International Journal of Engineering Applied Sciences and Technology, 2020 \\ Vol. 5, Issue 5, ISSN No. 2455-2143, Pages 37-45 \\ Published Online September 2020 in IJEAST (http://www.ijeast.com)}

local character, but Nasser's urbanization and architecture lost even such styles to benefit a non-cultural and nongeographical international style. The primary interest during the Nasser era was mega structures and mega-urban developments. The middle class was very fond of megaprojects.

The Nile Hilton Hotel was built before the political clash between Egypt and the USA. It is designed to represent the USA values at the beginning of the Cold War; modernity, luxury, efficiency, and comfort. It can be considered as a step towards Americanizing Cairo. Cairo Tower was the highest building in Egypt and the Middle East, adopting an Ancient Egyptian style and creating a non-Arabic image. However, it was a landmark of Egypt's architectural and construction excellence. Its completion was a matter of civic pride to 'express defiance of foreign influence in Egypt' (Selim 2016, 180). While the Arab League Headquarters presented very external Arabic decoration, its style and grandeur stood for Nasser's socialism and modernity values.

Identity is important in urban development because it implicates the self. It has consequences for cognition and behavior. Identity 'processes are embedded within wider, dynamic cultural, political, and economic forces' (DevineWright and Clayton 2010, 267). Thus, creating an identity should be recognized as a significant urban aim for the new Egyptian socialist state and Nasser's struggle for Arabism. Nasser's regime disconnected itself from the 'fogy' and retroactive past by promoting what was believed to be modern. Nasser's regime centralized the creation of all mega projects to bring back 'order' to the city, resolve the memories' problems, and realize Nasser's vision of modern urban identity. Hence, producing more authoritarian-power-orientedrepresentation projects.

Meanwhile, the Arab region was a centre stage of the global Cold War where superpowers competed for political, economic and cultural influence, offering military aid and soft power (movie industry) (Hanssen 2020). 'The imported state' is a statement suggested by Bertrand Badie to present a middle-east state constructed on westernized political, administrative, and cultural concepts.(Badie 2000) The European city model influenced the Egyptian imported state during the colonial era, the local cultural and socio-economic values. The highest, the most modern, and the largest were (and still are) beloved statements among the Egyptian authoritarian elites.

Both Heliopolis and Medinet Nasr are examples of invading the desert by the built environment. Despite the time difference between the two and their proximity, Heliopolis was not considered a role model by the Egyptian planner of Medinet Naser. Medinet Naser did not adapt Arabic styles, even superficial ones. It was introduced as the new administrative city and the center of authoritarian power. Like all static plans, Medinet Nasr fell under the imposed pressure of the 'naevus rich' returning from Gulf countries (S. A. Saad 1999). Its site was chosen near central military installations to ensure military control (El-Kadi 1990, 191-92). Egypt's first attempt to control Cairo's urbanization was with the 1956 Master Plan, which introduced British planning theories and recommended the construction of satellite towns. New satellite towns were a robust solution in the 1956 Master Plan to absorb the potential population growth.

Nevertheless, Nasser's regime's fear of diminishing its political control over the labor force prevented satellite towns' implementation (Serageldin 1985, 123) and shifted to suburban development. Since the villa was the primary residential type in Medinet Nasr, a bright contrast was created. The contrast was achieved due to the authoritarian building's grandeur that stood for the state's power and modernity against the villa size (Figure 7).

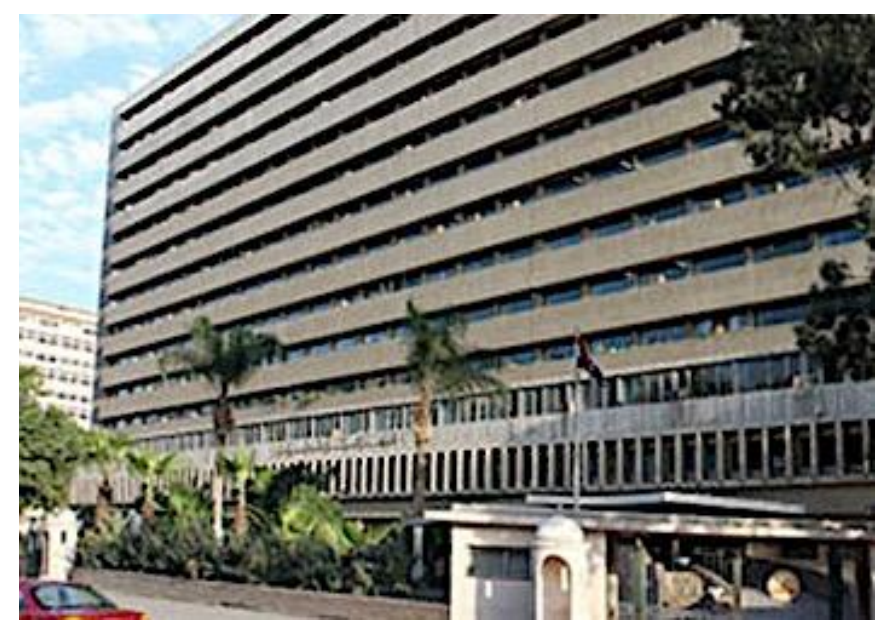

Fig. 7. The Accountability Central Authority building in Medinet Naser, the author

Medinet el-Sahafeyyen and Medinet el-Mohandseen among other districts were 'assigned to a particular professional occupation to set the exemplar life patterns for ordinary Egyptians living in new settlements' (Selim 2016, 184). Both of them were constructed western Cairo Down Town and across the river Nile. Interestingly, most of the Nasser iconic buildings were constructed within the Tahrir area and at the old Down Town's outskirts. The interest shown by the Nasser regime for centralizing its iconic buildings within the Tahrir area can be interpreted as a symbolic political competition with the past. Competing with the old monarchy's existing architecture in Down Town with a new central transportation node and iconic sites seems consistent with Nasser's policy for detaching 'now' from 'then.'

Similar to St. Petersburg's case in Russia, in which the 'Tsar Alexander built a chain of squares, one kilometer long, through which his human machines might march' (Banerjee and Southworth 1991, 413), Nasser promoted Tariq el-Nasr (Road of victory) in Medinet Nasser in which his army can parade, and replicated the Soviet-Stalinist boulevard's style (Föllmer 2018). Cairo's urban planning reveals how authoritarian power relations have been inscribed upon 


\section{International Journal of Engineering Applied Sciences and Technology, 2020 \\ Vol. 5, Issue 5, ISSN No. 2455-2143, Pages 37-45 \\ Published Online September 2020 in IJEAST (http://www.ijeast.com)}

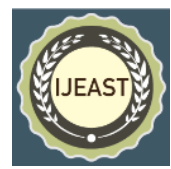

Egyptian social space (Dorman 2013). Nevertheless, to which degree those megaprojects represent the official policy of Arabism? The inconsistency between his political slogan, his iconic architecture and urban development answered such a question.

The emergence of new actors, the creation of unfamiliar planning processes, the public's disempowerment, achieving cultural and education control, led to extensive centralization for Cairo's urbanization, its function, and symbolism. Although the 'visual support to national ideologies' (Hein 2012, 374) should be demonstrated in the urban and architectural action taken on the ground, Nasser replaced modernism with westernization and neglected his Arabism slogan.

By entering a new 'state mode of production' (Brown 2013), the state played a central role in developing and legal regulating the urban spaces. To control the production of urban space as a method of controlling the community sociospatial relations. Because practicing control over the built environment means practicing control over the population (Miller and Nicholls 2013, 453). The centralized Egyptian state neglected Arabism in Cairo urbanization favoring its 'modernized' authoritarian image. Nevertheless, Arabism failed in facing the cumulative legacy of sociocultural powers in the Egyptian collective memory on different levels; the ruling and the intellectual.

\section{CONCLUSIONS}

Arabism was not more than a political slogan; Nasser's regime adapted European architectural and urbanization styles. His Arabism slogan remains superficial in terms of authoritarian urban development and architecture.

Despite its packaging in the Arabic language, Nasser's urban development was far from being 'Arabic.' Minimal and mostly personal efforts were made to support local identity, but Nasser's iron-grid of wide streets and building blocks emulated European urbanism ideals.

Western modern urbanization enhanced Nasser's regime; it allowed the state to practice its control and power representation.

Nasser's regime used the same urban colonialism tools, such as the visual vistas, celebrative and spectacles wide roads, open accessibility to residential areas, vast open spaces, authoritarian buildings overlooking central spaces, and disempowering the public. Consequently, its urban and architectural products did not promote what was politically presented.

Urban and architectural projects intended to change the old political system's symbolic meanings rather than create a local Arabic one. It created colonial urbanization but in a different appearance.

The main agenda of building new quarters (officially called cities) was to impose authoritarian control and power over the public. Nasser's urban and architectural achievements failed to symbolize his political agenda in action.

No radical urban changes found a place in Nasser's revolutionary slogans; superficial changes dominated his era.

Instead of stressing on Arabism as an urban and architectural identity, Nasser's authorities promoted westernization as a substitute for modernism.

Nasser fell into the colonial trap by promoting the European city as a role model for Egyptian urbanization.

\section{REFERENCES}

1 Abaza, Mona. 2011. 'Critical Commentary. Cairo’s Downtown Imagined Dubaisation or Nostalgia?' Urban Studies 48 (6): 1075-87. https://doi.org/10.1177/0042098011399598.

2 Allen, John. 2010. 'Powerful City Networks: More than Connections, Less than Domination and Control'. Urban Studies 47 (13): 2895-2911. https://doi.org/10.1177/0042098010377364.

3 Badie, Bertrand. 2000. The Imported State: The Westernization of the Political Order. Translated by: Claudia Royal. California: Stanford University Press.

4 Bale, Courtney, and Jeanniton Blake. 2017. 'Greater Cairo: From Patriotism to Privatization Urbanization \& Development'. 2017. https://www.academia.edu/35890501/Greater_Cairo_ From_Patriotism_to_Privatization_Urbanization_and _Development.

5 Banerjee, Tridib, and Michael Southworth. 1991. City Sense and City Design. Writing and Projects of Kevin Lynch. Cambridge, Massachusetts: The MIT Press.

6 Bernardo, F., and J. Palma-Oliveira. 2012. 'Place Identity: A Central Concept in Understanding Intergroup Relationships in the Urban Context'. In $H$. Casakin, \& F. Bernardo (Eds.), The Role of Place Identity in the Perception, Understanding, and Design of Built Environments, 45-62. Bentham.

7 Bianca, Stefano. 2000. Urban Form in the Arab World. Past and Present. London: Thames and Hudson.

8 Brown, Alison. 2013. "The "Right to the City": From Paris 1968 to Rio 2010'. Habitat International Coalition. Global Network for the Right to Habitat and Social Justice (blog). 2013. https://www.hicgs.org/articles.php?pid=6810.

9 Devine-Wright, Patrick, and Susan Clayton. 2010. 'Introduction to the Special Issue: Place, Identity and Environmental Behaviour'. Journal of Environmental $\begin{array}{llll}\text { Psychology } & 30 & \text { (3): }\end{array}$ https://doi.org/10.1016/S0272-4944(10)00078-2.

10 Dorman, W. J. 2013. 'Exclusion and Informality: The Praetorian Politics of Land Management in Cairo, Egypt'. International Journal of Urban and Regional 


\section{International Journal of Engineering Applied Sciences and Technology, 2020 \\ Vol. 5, Issue 5, ISSN No. 2455-2143, Pages 37-45 \\ Published Online September 2020 in IJEAST (http://www.ijeast.com)}

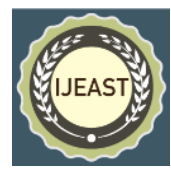

$\begin{array}{llll}\text { Research } & 37 & (5): & 1584-1610 . \\ \text { https://doi.org/10.1111/j.1468-2427.2012.01202.x. }\end{array}$

Dunn, Nicole. n.d. 'Nasser and the Third World Project'. Accessed 17 March 2020. https://www.academia.edu/26510069/Nasser_and_th e_Third_World_Project.

12 El-Kadi, Galila. 1990. 'Trent Ans de Planification Urbaine Au Caire'. Revue Tiers-Monde 31 (121): 185-207.

13 Föllmer, Moritz. 2018. 'Urban Individuality and Urban Governance in Twentieth-Century Europe'. In Gunn, Simon and Hulme, Tom (Eds.) Powers of the City: New Approaches to Governance and Rule in Urban Europe Since 1500, https://www.academia.edu/43670170/Urban_Individ uality_and_Urban_Governance_in_Twentieth-

Century_Europe. London: Routledge.

14 Hanssen, Jens. 2020. 'Crisis and Critique: The Transformation of the Arab Radical Tradition, 1960s1980s'. In Guirguis, Laure. The Arab Lefts: Histories and Legacies, 1950s-1970s, Chapter 12. Edinburgh: The Edinburgh University Press. https://www.academia.edu/40876040/Crisis_and_Crit ique_The_Transformation_of_the_Arab_Radical_Tra dition_1960s-1980s.

15 Haykal, Hassanien. 1961. Azmat al-muthaqqafin (The Crisis of the Intellectuals). Cairo: Dar el-Udaba.

16 Hein, Carola. 2012. 'Spaces of Identity in East European Cities'. Journal of Urban History 38 (2): 372-78. https://doi.org/10.1177/0096144211427120.

17 Hiller, Bill, and Shinichi Iida. 2005. 'Network Effect and Psychological Effect: A Theory of Urban Movement'. In , 553-64. New York.

18 Karim, Sayed. n.d. The Socialist Villa. Cairo: ElNahda el-Masreya.

19 Kavoura, Christina. n.d. 'Urban Social Movements and the Political: The Movements of Athens and Istanbul'. Accessed 23 March 2020. https://www.academia.edu/36863110/Urban_Social_ Movements_and_the_Political_the_movements_of_ Athens_and_Istanbul.

20 Kumar, Raj. 2017. 'Overview: Social Spaces in Urban Areas'. International Journal of Engineering and Technology 4 (4): 1032-39.

21 Maksoud, Klufis. 1960. Azma al-yasar al-'arabi (The Crisis of the Arab Left). Beirut: Dar el-Ilm lilMalayien.

22 Medinet Nasr Company (Ed.). 2019. 'The Technical Annual Report of Medinet Nasr'. Cairo.

23 Miller, Byron, and Walter Nicholls. 2013. 'Social Movements in Urban Society: The City as A Space of Politicization'. Urban Geography 34 (4): 452-73. https://doi.org/10.1080/02723638.2013.786904.

24 Mitchell, Timothy. 1991. Colonising Egypt. Berkeley: University of California Press.
25 Moor, A. 1994. Images of Development: Egyptian Engineers in Search of Industry. Cairo: The AUC Press.

26 Nasser, Gamal. n.d. La Philosophie de la revolution. Cairo: n. p.

27 . 1962. 'Speech delivered by Gamal Abdel Nasser on the occasion of the Tenth Anniversary of the Revolution'. Cairo.

28 Norberg-Schulz, Christian. 1991. Genius Loci: Towards a Phenomenology of Architecture Use. New York: Rizzoli.

29 Pflieger, Géraldine, and Céline Rozenblat. 2010. 'Introduction. Urban Networks and Network Theory: The City as the Connector of Multiple Networks'. Urban Studies 47 (13): 2723-35. https://doi.org/10.1177/0042098010377368.

30 Pierce, Josef, Deborah Martin, and James Murphy. 2010. 'Relational Place-Making: The Networked Politics of Place'. Royal Geographical Society.

31 Rabbat, Nasser. 2010. Mamluk History through Architecture. Monuments, Culture, and Politics in Medieval Egypt and Syria. Cairo: AUC Press.

32 . 2011. 'Circling the Square: Architecture and Revolution in Cairo'. Artforum 49 (April): 182-91.

33 Saad, Sadek. 2018. 'The Spatial Identity of Historic Cairo. Part Two: Must Prominent Buildings Be Enframed?' In , 1:183-94. Cairo: EREK and Springer.

34 . 2019. 'Cairo in The Age of Great Urban Transformations. Changes in Street Patterns Only, or a Shift in Power Networks as Well?' In The Future and the Built Environment, 389-408. Istanbul: Fatih Sultan Mehmet Universitesi.

35 2020. Kahiret el-Thahaworat el-Kobra. (1805-1950) 'Great Urban Deformations' Cairo (1805-1950)'. Cairo: Kotobna.

36 Saad, Sadek A. 1999. 'Functional Distribution of Commercial services in Contemporary Cairene Centers. Case Study: Medinet Nasr'. In , 2:1-10. Port Saiad, Egypt: University of Suez Canal.

37 Sabaseviciute, Giedre. 2011. 'Re-Creating the Past: The Manipulation of the Notion of Rupture in Egyptian Revolutions'. Cahier de l'Insitut d'histoire de La Revolution Francaise 5: 1-12.

38 Sadek, Said. 2006. 'Cairo as Global/Regional Cultural Capital?' In Singerman, Diana and Amar, Paul (Eds.) Cairo Cosmopolitan: Politics, Culture, and Urban Space in the New Globalized Middle East, 153-90. Cairo: The AUC Press.

39 Scott, J.C. 1998. Seeing Like a State: How Certain Schemes to Improve the Human Conditions Have Failed. New Haven, CT.: Yale University Press.

40 Selim, Gehan. 2016. 'Between Order and Modernity Resurgence Planning in Revolutionary Egypt'. 
Journal of Urban History 42 (1): 180-200. https://doi.org/10.1177/0096144214566980.

41 Serageldin, M. 1985. 'Planning and Institutional Mechanisms'. In Proceedings of Seminar Nine in the Series Architectural Transformations in the Islamic World. Cairo: The Aga Khan Award for Architecture.

42 Sims, David. 2012. Understanding Cairo: The Logic of a City Out of Control. Cairo: AUC Press.

43 Sudradjat, Iwan. 2012. 'Foucault, the Other Spaces, and Human Behaviour'. Procedia - Social and Behavioral Sciences 36: 28-34. https://doi.org/10.1016/j.sbspro.2012.03.004.

44 Talen, Emily. 2012. 'Zoning and Diversity in Historical Perspective'. Journal of Planning History $11 \quad$ (4): 330-47. https://doi.org/10.1177/1538513212444566.

45 Uitermark, Justus, Walter Nicholls, and Maarten Loopmans. 2012. 'Cities and Social Movements: Theorizing beyond the Right to the City'. Environment and Planning A, January. https://doi.org/10.1068/a44301.

46 Webster, Chris. 2007. 'Property Rights, Public Space and Urban Design'. The Town Planning Review 78 (1): 81-101. https://doi.org/10.2307/40112703.

47 Westhuizen, Diaan van der, and Jason Cloen. 2012. 'Conceptions of Space in the Evolution of a Gridded and an Organic Town: Bloemfontein and Kimberley, South Africa'. Procedia - Social and Behavioral Sciences 50: 318-32. https://doi.org/10.1016/j.sbspro.2012.08.037.

48 Zad, Vahid Vahdat. 2013. 'Spatial Discrimination in Tehran's Modern Urban Planning 1906-1979'. Journal of Planning History 12 (1): 49-62. https://doi.org/10.1177/1538513212459717. 